\title{
Exclusion of Pregnant Women from Clinical Trials during the Coronavirus Disease 2019 Pandemic: A Review of International Registries
}

\author{
Devin D. Smith, MD ${ }^{1}$ Jessica L. Pippen, MD ${ }^{1}$ Adebayo A. Adesomo, MD ${ }^{2}$ Kara M. Rood, MD \\ Mark B. Landon, $\mathrm{MD}^{1}$ Maged M. Costantine, MD
}

${ }^{1}$ Division of Maternal-Fetal Medicine, Department of Obstetrics and Gynecology, The Ohio State University College of Medicine, Columbus, Ohio

2 Department of Obstetrics and Gynecology, The Ohio State

University College of Medicine, Columbus, Ohio

Address for correspondence Devin D. Smith, MD, Department of Obstetrics and Gynecology, Ohio State University, 395 West 12th Avenue, 5th Floor, Columbus, $\mathrm{OH} 43210$ (e-mail: devin.smith@osumc.edu).

Am J Perinatol 2020;37:792-799.

\begin{abstract}
Keywords

- coronavirus

- COVID-19

- exclusion

- pregnancy

- research

Objective Pregnant women have been historically excluded from clinical trials for nonobstetric conditions, even during prior epidemics. The objective of this review is to describe the current state of research for pregnant women during the coronavirus disease 2019 (COVID-19) pandemic.

Study Design We conducted a search of international trial registries for trials relating to the novel coronavirus. The eligibility criteria for each trial were reviewed for inclusion/ exclusion of pregnant women. Relevant data were extracted and descriptive statistics were calculated for individual and combined data. The total number of trials from each registry were compared, as well as the proportions of pregnancy-related trials within each.

Results Among 621,370 trials in the World Health Organization International Clinical Trials Registry, 927 (0.15\%) were COVID-19 related. Of those, the majority (52\%) explicitly excluded pregnancy or failed to address pregnancy at all $(46 \%)$ and only $16(1.7 \%)$ were pregnancy specific. When categorized by region, 688 (74.2\%) of COVID-19 trials were in Asia, followed by 128 (13.8\%) in Europe, and 66 (7.2\%) in North America. Of the COVID-19 trials which included pregnant women, only three were randomized-controlled drug trials. Conclusion Approximately $1.7 \%$ of current COVID-19 research is pregnancy related and the majority of trials either explicitly exclude or fail to address pregnancy. Only three interventional trials worldwide involved pregnant women. The knowledge gap concerning the safety and efficacy of interventions for COVID-19 created by the exclusion of pregnant women may ultimately harm them. While "ethical" concerns about fetal exposure are often cited, it is in fact unethical to habitually exclude pregnant women from research.
\end{abstract}

\section{Key Points}

- Pregnancy was excluded from past pandemic research.

- Pregnancy is being excluded from COVID-19 research.

- Exclusion of pregnant women is potentially harmful.

received

April 20, 2020

accepted after revision

April 24, 2020

published online

May 19, 2020
Copyright $\odot 2020$ by Thieme Medical

Publishers, Inc., 333 Seventh Avenue, New York, NY 10001, USA. Tel: +1(212) 760-0888.
DOI https://doi.org/ 10.1055/s-0040-1712103. ISSN 0735-1631. 
Pregnant women have been historically excluded from clinical and pharmacologic trials for nonobstetric conditions. This is due to several factors including "ethical" concerns about fetal exposure, liability risk, lack of interest from pharmaceutical companies, and complex regulations. ${ }^{1}$ of all industry-sponsored trials in the United States in 2013 , only $1 \%$ were specifically designed for pregnant women and $98 \%$ of trials that involved a drug or device excluded them. ${ }^{2}$ On the other hand, the proportion of pregnant women with coexisting medical conditions continues to rise likely due to advanced age at the time of pregnancy and higher rates of obesity and medical comorbidities, such as diabetes, hypertension, and depression, among others. With approximately $25 \%$ of pregnant women entering pregnancy with a medical condition or developing pregnancy-related morbidity, the rate of medication use in pregnancy has increased greatly. ${ }^{3}$ In 2015, pregnant women were using on average four medications during pregnancy with almost half of them using four or more medications during pregnancy. ${ }^{3-5}$ These factors place pregnant women at a disadvantage given that the vast majority of medications to treat nonobstetrical conditions were never tested in pregnancy. ${ }^{6}$

The current state of research in pregnancy and the pattern of excluding pregnant women from drug trials is dismal at best and has not significantly improved even with recent improvements in the regulatory area. ${ }^{7,8}$ It is thus unsurprising that in the face of a global pandemic, pregnant women remain therapeutic orphans and are yet again left out of academic-and industry-sponsored investigations critical to the advancement of treatment.

Coronavirus disease 2019 (COVID-19) is an emerging infection caused by a novel coronavirus (severe acute respiratory syndrome coronavirus 2 [SARS-CoV-2]) that was first detected in Wuhan, China in late December 2019. The disease has since rapidly spread across the globe and was categorized as a pandemic by the World Health Organization (WHO) on March 11, 2020. As of April 7, 2020, more than 1.3 million cases of SARS-CoV-2 have been confirmed worldwide, with nearly 80,000 related deaths. ${ }^{9-11}$ Given the inability of governments across the world to contain the infection and a lack of effective therapeutics or vaccines, federal entities and pharmaceutical companies are rushing to develop life-saving interventions. Best practices are not available for obstetric care, and pregnant women may once again be excluded from effective therapeutics and from participating in clinical trials.

We undertook this study with the objective to review the current state of research for pregnant women during the COVID-19 pandemic by surveying the world's clinical trial registries to ascertain the number, location, and type of registered studies that include pregnant women.

\section{Materials and Methods}

\section{Data Sources and Study Selection}

On April 7, 2020, we conducted a search of the WHO International Clinical trials registry platform (ICTRP). A detailed export of all registered COVID-19 related trials was extracted and used for this study. The export was reviewed in its entirety and meticulously examined for trials which included pregnant subjects. Specifically, the eligibility criteria for each trial were reviewed for inclusion/exclusion of pregnant women. Trial registration pages were translated to English when necessary. Thereafter, select national registries represented by the WHO trial export were queried for completeness. Included registries met the requirements of the International Committee of Medical Journal Editors for content, quality, and validity. Each registry was first queried for COVID-19 and then filtered by pregnancy. Countries and continents represented in the individual registries reviewed included the United States, Australia/New Zealand, United Kingdom, European Union, Japan, Iran, India, China, the Netherlands, Germany, Canada, Korea, Brazil, Pan-Africa, Thailand, Cuba, and Sri Lanka (-Table 1). Finally, the WHO export and the trials identified via the national registries search were cross-referenced for completeness and to exclude any duplicates. For registries that had limited search functions, individual inspection of registered trials was done.

For this review, we included all registered clinical trials related to COVID-19, irrespective of trial design or language. We also did not specify a date range since this is a novel pandemic and included all trials through the day of our search. Our primary objective was to describe current research relating to pregnant women during the COVID-19 pandemic. Therefore, we narrowed our search using the following terms "COVID-19" and "pregnancy" or "pregnant" and all registered trials (e.g., observational and interventional) were included. A secondary aim was to evaluate inclusion of pregnant women in COVID-related pharmaceutical interventional trials using any pharmacologic agents, supplements, or vaccines.

\section{Data Extraction}

For all relevant trials, data were extracted from the selected registries and organized using Microsoft Excel. Variables of interest included name of trial, trial website, associated registry, study type (observational or interventional; prospective or retrospective; case series, cohort, registry, or randomized-controlled), intervention type, sponsor type, sponsor location, inclusion of pregnant subjects, and whether the trial design was specific to pregnancy.

\section{Data Analysis}

All relevant trials were combined across registries and filtered to exclude duplicates, and data were analyzed collectively. Descriptive statistics were calculated using Microsoft Excel for individual and combined data. The total number of trials from each registry was compared as well the proportions of pregnancy-related trials within each registry. The country of sponsorship for each trial was used for the analysis by region and country.

\section{Results}

We reviewed 18 research registries (-Table 1 ). Of the 621,370 trials in the WHO International Clinical trials registry (as of April 7, 2020), 927 were COVID-19 related representing $0.15 \%$ of total trials ( - Fig. 1 ). Of these 927 COVID-19 trials, the vast majority (52\%) explicitly excluded pregnancy 


\begin{tabular}{|c|c|c|c|c|c|}
\hline Name of Registry & Registry URL & Country & $\begin{array}{l}\text { Total } \\
\text { trials }\end{array}$ & COVID-19 & $\begin{array}{l}\text { COVID-19+ } \\
\text { pregnancy }^{\mathrm{a}}\end{array}$ \\
\hline $\begin{array}{l}\text { International Clinical } \\
\text { Trials Registry Platform }\end{array}$ & https://www.who.int/ictrp/en/ & World & 621,370 & $927(0.15)$ & $16(1.7)$ \\
\hline Clinicaltrials.gov & https://clinicaltrials.gov & World & 335,447 & $388(0.12)$ & $5(1.3)$ \\
\hline $\begin{array}{l}\text { Australian New Zealand } \\
\text { Clinical Trials Registry }\end{array}$ & http://www.anzctr.org.au & $\begin{array}{l}\text { Australia/ } \\
\text { New Zealand }\end{array}$ & 27,003 & $15(0.06)$ & $1(6.7)$ \\
\hline $\begin{array}{l}\text { International Standard } \\
\text { Registered } \\
\text { Clinical/Social Study } \\
\text { Number }\end{array}$ & http://www.isrctn.com/ & United Kingdom & 19,292 & $12(0.06)$ & $1(8.3)$ \\
\hline $\begin{array}{l}\text { European Union Clinical } \\
\text { Trials Register }\end{array}$ & https://www.clinicaltrialsregister.eu & European Union & 36,866 & $48(1.3)$ & $1(2.1)$ \\
\hline $\begin{array}{l}\text { Japan Primary Registry } \\
\text { Network }\end{array}$ & http://rctportal.niph.go.jp/en/ & Japan & 44,765 & $41(0.09)$ & 0 \\
\hline $\begin{array}{l}\text { Iranian Registry of Clin- } \\
\text { ical Trials }\end{array}$ & www.irct.ir/ & Iran & 23,973 & $61(0.25)$ & 0 \\
\hline $\begin{array}{l}\text { Clinical Trials Registry- } \\
\text { India }\end{array}$ & http://ctri.nic.in/Clinicaltrials/login.php & India & $\mathrm{n} / \mathrm{a}$ & 6 & 0 \\
\hline $\begin{array}{l}\text { Chinese Clinical Trial } \\
\text { Registry }\end{array}$ & www.chictr.org/en/ & China & 31,344 & $529(1.7)$ & $4(0.76)$ \\
\hline $\begin{array}{l}\text { The Netherlands Na- } \\
\text { tional Trial Register }\end{array}$ & www.trialregister.nl/trialreg & Netherlands & 8,511 & $22(0.26)$ & $1(4.5)$ \\
\hline $\begin{array}{l}\text { German Clinical Trials } \\
\text { Register }\end{array}$ & https://drks-neu.uniklinik-freiburg.de/drks_web/ & Germany & 9,541 & $6(0.06)$ & 0 \\
\hline $\begin{array}{l}\text { Health Canada Clinical } \\
\text { Trials Database }\end{array}$ & http://ctdb-bdec.hc-sc.gc.ca & Canada & 2,850 & $6(0.21)$ & 0 \\
\hline $\begin{array}{l}\text { Clinical Research Infor- } \\
\text { mation Service, Repub- } \\
\text { lic of Korea }\end{array}$ & https://cris.nih.go.kr/cris/en & Korea & 4,884 & 0 & 0 \\
\hline $\begin{array}{l}\text { Brazilian Clinical Trials } \\
\text { Registry }\end{array}$ & www.ensaiosclinicos.gov.br/ & Brazil & 3,957 & $3(0.08)$ & 0 \\
\hline $\begin{array}{l}\text { Pan African Clinical Trial } \\
\text { Registry }\end{array}$ & www.pactr.org/ & $\begin{array}{l}\text { African } \\
\text { continent }\end{array}$ & $\mathrm{n} / \mathrm{a}$ & 1 & 0 \\
\hline $\begin{array}{l}\text { Thai Clinical Trials } \\
\text { Registry }\end{array}$ & www.clinicaltrials.in.th/ & Thailand & $\mathrm{n} / \mathrm{a}$ & 4 & 0 \\
\hline $\begin{array}{l}\text { Cuban Public Registry of } \\
\text { Clinical Trials }\end{array}$ & http://registroclinico.sld.cu/en/home & Cuba & $\mathrm{n} / \mathrm{a}$ & 0 & 0 \\
\hline $\begin{array}{l}\text { Sri Lanka Clinical Trials } \\
\text { Registry }\end{array}$ & www.slctr.lk/ & Sri Lanka & $\mathrm{n} / \mathrm{a}$ & 0 & 0 \\
\hline
\end{tabular}

Abbreviations: COVID-19, coronavirus disease 2019; n/a, not applicable.

Registries were not mutually exclusive.

"Number of COVID-19 trials that included "pregnant women" or "pregnancy."

Data reported as $n(\%)$ with the \% calculated using the number of COVID-19 trials as denominator.

or failed to address pregnancy at all (46\%) and only $16(1.7 \%)$ were pregnancy related (-Table 1 ). Of the 335,447 trials registered on the ClinicalTrials.gov registry, 388 (0.1\%) were COVID-19 related and only $5(1.3 \%)$ were pregnancy related (-Table 1).

When categorized by region (based on country of sponsorship), 688 (74.2\%) of the COVID-19 trials were in Asia, followed by 128 (13.8\%) in Europe, and 66 (7.2\%) in North America (-Fig. 2). When categorized by country of sponsorship, 677 (73\%) of the COVID-19 trials were in China, followed by $54(5.8 \%)$ in the United States, and 29 (3.1\%) in France (-Table 2). The registries with the highest proportions of COVD-19 pregnancy-related research were those of the United Kingdom (8.3\%), Australia/New Zealand (6.7\%), the Netherlands (4.5\%), European Union (2.1\%), ICTRP (1.7\%), and Clinicaltrials.gov (1.3\%) (-Table 1). The countries with the highest number of individual COVID-19 pregnancy-related trials were China $(n=4)$, France $(n=4)$, Italy $(n=2)$, and the United States $(n=2)$.

Review of the individual registries led to the inclusion of two additional pregnancy-related COVID-19 studies from Turkey. Of the 18 unique COVID-19 trials identified which included pregnant women, only 3 were randomized-controlled trials representing $0.3 \%$ of all COVID-19 studies and $1.8 \%$ of the 163 randomized interventional COVID-19-related trials. Those three pregnancy trials aimed to evaluate the use 




Fig. 1 WHO registry breakdown by type. WHO, World Health Organization.

of sarilumab (a human interleukin-6 receptor monoclonal antibody used for rheumatoid arthritis), honeysuckle (a Chinese traditional medicine), and high-dose vitamin $C$ in COVID-19 (-Table 3). The latter study using high-dose vitamin $\mathrm{C}$, in addition to the other additional Turkish trial, was subsequently removed from the clinicaltrials.govregistry. While none of these interventional trials were in the United States, there was one registered American interventional study, though not pharmacologic, which is investigating the use of a mobile application in evaluating perceived stress during the COVID-19 pandemic. Of the 18 COVID-19 pregnancy-related trials, 13 were sponsored by universities (72\%), 1 by government (6\%), 1 by industry (6\%), and 3 by other entities (16\%) (-Table 3 ). At the time of this study, there were three COVID-19 pregnancy-specific registries based out of the University of California (United States), Federico II University (Italy), and the University of Melbourne (Australia). The remaining studies included retro- spective and prospective cohort trials and case series (-Table 3 ).

Of the total COVID-19 trials, nine were vaccine trials and all of them explicitly excluded pregnancy.

\section{Discussion}

In this study, we demonstrated that less than $2 \%$ of all COVID19 registered trials include pregnant women, and only 3 were randomized-controlled trials involving the use of a medication/supplement (1.8\% of all COVID-19 randomized interventional trials). This dismal inclusion of pregnant women in clinical therapeutic research is not only disappointing but misguided, unjustified, and unfortunately familiar.

In 1993, the National Institute of Health passed the "Revitalization Act," which was meant to counteract a 1977 Food and Drug Administration's guideline prohibiting 


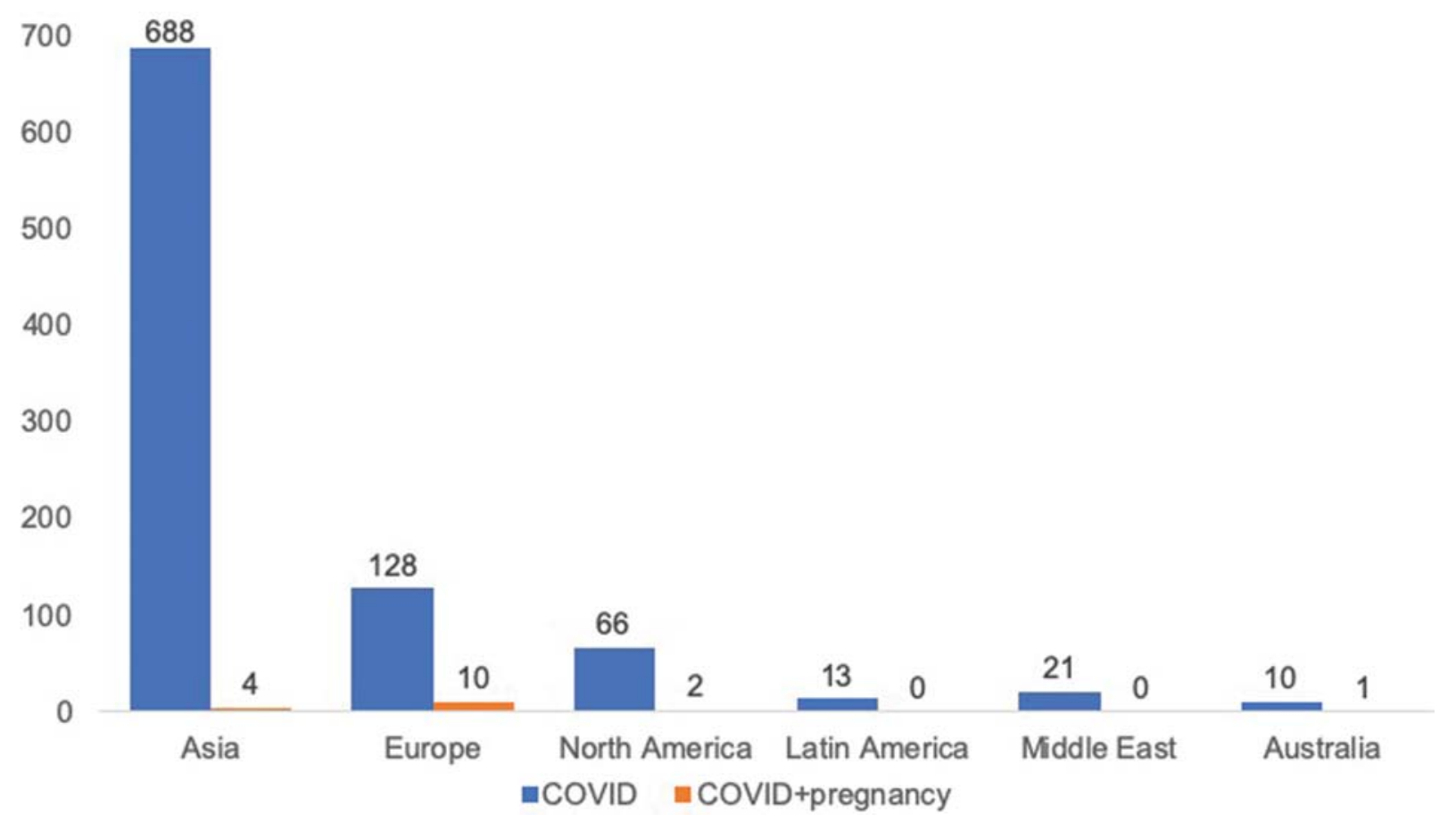

Fig. 2 WHO registry trials by region. COVID, coronavirus disease; WHO, World Health Organization.

reproductive-aged women from phase I and early phase II clinical trials. Prior to the Revitalization Act, women were largely excluded from participating in trials using pharmaceutical agents and there was growing concern that the process of drug development did not appropriately evaluate effects in female patients. ${ }^{3}$ The systematic exclusion of women from research paralleled a similar exclusion of pediatric patients from clinical trials prior to the Best Pharmaceuticals for Children and Pediatrics Research Equity Acts of 1994. These efforts led to a dramatic shift in the culture of pediatric research. ${ }^{12}$ Today, the inclusion of women in clinical trials is both expected and commonplace though usually requires that a subject be nonpregnant and/or compliant with effective contraception. ${ }^{13}$ However, pregnant women remain habitually excluded from clinical pharmacologic/ therapeutic trials that do not address obstetric conditions. This is due, in large part, to potential risks of teratogenicity weighed against potential medical benefits to the mother. Unfortunately, the "ethical" concerns of including pregnant women in research has predominantly trumped maternal benefits in the eyes of society and regulatory bodies. ${ }^{3}$ The HIV/AIDS epidemic serves as a singular and excellent example of inclusion of pregnant women in the earliest phases of drug development. ${ }^{13}$ However, this was predominantly driven by the potential benefit of reduced vertical transmission to the fetus. ${ }^{14}$

Unfortunately, the pattern of excluding pregnant women from clinical trials, even during epidemics, is not new. As an example, seasonal vaccination of pregnant women against influenza has been a recommendation of the WHO since 2005, though was not practiced widely until after the influenza pandemic of 2009. ${ }^{15}$ During the global H1N1 pandemic, pregnant women were notably and disproportionately af- fected. Although pregnant women represented only $1 \%$ of the U.S. population at the time, they accounted for $5 \%$ of U.S. deaths and nearly $10 \%$ of hospitalizations related to the virus. $^{16,17}$ Some experts attributed the higher mortality rates, in part, to the use of inadequate doses of oseltamivir. ${ }^{18}$ In the aftermath of the pandemic, many researchers urged the scientific community to increase the inclusion of pregnant women in pharmacologic trials, which could potentially benefit that population during future crises. ${ }^{19}$

However, in the face of the 2013 Ebola epidemic, pregnant patients were again near universally excluded from treatment studies. Despite recommendations from experts to include pregnant subjects, citing both ethical and medical motives, they were excluded from almost all drug and vaccine trials in affected countries. Reasons for exclusion were most often potential fetal harm, financial and logistical challenges, or none at all. This occurred despite the fact that Ebola was highly lethal for pregnant women and their fetuses. Once again, pregnant women were denied autonomy and their right to decide, and were deprived the same access to potentially lifesaving interventions as other poplations."13 Exclusion from drug-related research is additionally detrimental when it leads to medication use for "off-label" indications or at doses not specifically studied in pregnant women. In this setting, the mother and fetus are exposed to potential harms that could have been avoided through rigorous scientific testing. ${ }^{20}$

The H1N1 and Ebola crises serve as important historic examples of the danger of excluding pregnant women from important research. At the time of this study, more than 1.3 million cases of SARS-CoV-2 have been confirmed worldwide with nearly 80,000 related deaths. ${ }^{9-11}$ The exclusion of pregnant women is particularly damaging as the SARS-CoV-2 is likely to circulate the globe until a massive and effective 


\begin{tabular}{|c|c|c|c|}
\hline Region & Country & COVID-19 & $\begin{array}{l}\text { COVID-19+ } \\
\text { pregnancy }\end{array}$ \\
\hline \multirow[t]{17}{*}{ Europe } & United Kingdom & 17 & 2 \\
\hline & Ireland & 1 & 0 \\
\hline & Netherlands & 12 & 1 \\
\hline & Germany & 6 & 0 \\
\hline & Belgium & 7 & 0 \\
\hline & Denmark & 6 & 0 \\
\hline & France & 29 & 4 \\
\hline & Greece & 3 & 0 \\
\hline & Italy & 22 & 2 \\
\hline & Norway & 6 & 0 \\
\hline & Poland & 1 & 0 \\
\hline & Romania & 2 & 0 \\
\hline & Scotland & 1 & 0 \\
\hline & Spain & 9 & 1 \\
\hline & Sweden & 2 & 0 \\
\hline & Switzerland & 4 & 0 \\
\hline & Total & 128 & 9 \\
\hline \multirow[t]{6}{*}{ Latin America } & Brazil & 5 & 0 \\
\hline & Colombia & 2 & 0 \\
\hline & Argentina & 1 & 0 \\
\hline & French Guiana & 1 & 0 \\
\hline & Mexico & 4 & 0 \\
\hline & Total & 13 & 0 \\
\hline Australia & & 10 & 1 \\
\hline \multirow[t]{3}{*}{ North America } & United States & 54 & 2 \\
\hline & Canada & 12 & 0 \\
\hline & Total & 66 & 2 \\
\hline \multirow[t]{7}{*}{ Asia } & China & 677 & 4 \\
\hline & Japan & 5 & 0 \\
\hline & Pakistan & 1 & 0 \\
\hline & Singapore & 1 & 0 \\
\hline & South Korea & 3 & 0 \\
\hline & Vietnam & 1 & 0 \\
\hline & Total & 688 & 4 \\
\hline \multirow[t]{7}{*}{ Middle East } & Egypt & 2 & 0 \\
\hline & Iran & 11 & 0 \\
\hline & Israel & 3 & 0 \\
\hline & Jordan & 1 & 0 \\
\hline & Saudi Arabia & 1 & 0 \\
\hline & Turkey & 3 & 0 \\
\hline & Total & 21 & 0 \\
\hline
\end{tabular}

Abbreviations: COVID-19, coronavirus disease 2019; WHO, World Health Organization.

Note: One trial was unable to be assigned a sponsor country (WHO-sponsored multicountry clinical trial).

vaccination program is implemented. Findings from current research that have excluded pregnant women may not be applicable to the pregnant population. This lack of generaliz- ability is often due to well-known physiologic changes in pregnancy which affect the pharmacokinetic and pharmacodynamic properties of drugs. The knowledge gap concerning the safety and efficacy of interventions for COVID-19 created by the exclusion of pregnant women may ultimately harm them. While "ethical" concerns about potential fetal exposure are often cited, it is in fact unethical to habitually exclude pregnant women from research.

Even more concerning, in our review we only identified two drug trials which explicitly included pregnant subjects. At the time of this study, hydroxychloroquine and azithromycin are among the most promising and studied interventions for COVID-19. However, of the 42 trials we identified which evaluated hydroxychloroquine and/or azithromycin use, 36 trials explicitly excluded pregnant subjects and 6 failed to address pregnancy in their criteria. This is despite the fact that these medications have been used for decades in pregnancy (for systemic lupus erythematosus, malaria, community-acquired pneumonia, preterm premature rupture of membranes, and chlamydia) with well-established safety profiles.

Our study is limited by its descriptive nature and inclusion criteria. Though we primarily included WHO-registered clinical trials to ensure quality and cross-checked the WHO registry against multiple individual registries, there may be relevant trials that were not captured by our analysis. If so, we believe that number to be very small. Additionally, the lack of consistent and effective search functions across each database made some information inaccessible via individual registry query. Furthermore, several trials did not address "pregnancy" within the eligibility criteria. It is likely that few pregnant women enrolled in these trials; however, it may be plausible that some of these studies allowed the inclusion of pregnant women. Lastly, we were limited by how quickly the databases changed and acknowledged that the numbers represented by our April 7, 2020 assessment may be different than those in the near future. However, we believe the major strengths of our study to be its contextual importance, systematic and unbiased approach, global inclusivity, and rigorous data filtering and analysis.

We are currently facing yet another infectious disease crisis and with so few active trials addressing COVID-19 in pregnancy, we fear that history is repeating itself. The original intentions that underlaid the exclusion of pregnant subjects from research were nonmaleficent. However, in an effort to protect mothers and their fetuses from research-related risks, both will be placed at potentially greater risks related to the use of understudied or off-label treatments. Improving maternal and fetal health requires that we engage pregnant women appropriately in clinical research. Inclusion will allow women to make autonomous and evidence-based decisions, which ultimately protects this scientifically complex (not "vulnerable") population through research rather than from it. ${ }^{21}$ Pregnant women should be given the opportunity to be included in COVID-19 clinical trials based on the universal concepts of justice, equity, autonomy, and informed consent. We call upon professional organizations both in the United States and worldwide to continue to advocate for the timely inclusion of pregnant women in appropriate trials. 
Table 3 Trials that included pregnant subjects

\begin{tabular}{|c|c|c|c|c|c|c|}
\hline Name & Location & Sponsor & Type & & & $\begin{array}{l}\text { Pregnancy- } \\
\text { specific } \\
\text { design }\end{array}$ \\
\hline $\begin{array}{l}\text { A randomized controlled trial for hon- } \\
\text { eysuckle decoction in the treatment of } \\
\text { patients with novel COVID- } 19 \text { infection }\end{array}$ & China & $\begin{array}{l}\text { Nanjing Second Hospital } \\
\text { (University) }\end{array}$ & Interventional & Prospective & $\mathrm{RCT}$ & No \\
\hline $\begin{array}{l}\text { An adaptive phase } 2 / 3 \text {, randomized, } \\
\text { double-blind, placebo-controlled, } \\
\text { study assessing efficacy and safety of } \\
\text { sarilumab for hospitalized patients } \\
\text { with COVID-19 }\end{array}$ & France & $\begin{array}{l}\text { Sanofi Aventis Research } \\
\text { and Development } \\
\text { (Industry) }\end{array}$ & Interventional & Prospective & $\mathrm{RCT}$ & No \\
\hline $\begin{array}{l}\text { Evaluation of the effect of high-dose } \\
\text { vitamin C use in COVID-19 positive } \\
\text { pregnants }^{\text {a }}\end{array}$ & Turkey & $\mathrm{n} / \mathrm{a}$ & Interventional & Prospective & Cohort & Yes \\
\hline $\begin{array}{l}\text { Effects of using mobile app on per- } \\
\text { ceived stress during coronavirus } \\
\text { (“COVID-19") pandemic }\end{array}$ & United States & University of Arizona & Interventional & Prospective & $\mathrm{RCT}$ & Yes \\
\hline $\begin{array}{l}\text { Evaluation of blood results of COVID-19 } \\
\text { positive pregnants }^{\text {a }}\end{array}$ & Turkey & $\mathrm{n} / \mathrm{a}$ & Observational & Prospective & Cohort & Yes \\
\hline $\begin{array}{l}\text { Maternal and neonatal outcomes from } \\
\text { women infected with SARS-COV2 } \\
\text { (COVID-19) during pregnancy }\end{array}$ & Australia & University of Melbourne & Observational & Prospective & Registry & Yes \\
\hline $\begin{array}{l}\text { Establishment of an early warning } \\
\text { model for maternal and child vertical } \\
\text { transmission of COVID-19 infection }\end{array}$ & China & $\begin{array}{l}\text { Huazhong University of } \\
\text { Science and Technology } \\
\text { (University) }\end{array}$ & Observational & Retrospective & Case series & Yes \\
\hline $\begin{array}{l}\text { Study for the impact on fetus and } \\
\text { neonates of vertical transmission of } \\
\text { 2019-nCoV }\end{array}$ & China & $\begin{array}{l}\text { Huazhong University of } \\
\text { Science and Technology } \\
\text { (University) }\end{array}$ & Observational & Retrospective & Case series & Yes \\
\hline $\begin{array}{l}\text { Retrospective analysis of anesthesia } \\
\text { management of emergency cesarean } \\
\text { section in nonpneumonia hospital of } \\
\text { Wuhan during pandemic of novel co- } \\
\text { ronavirus pneumonia (COVID-19) }\end{array}$ & China & $\begin{array}{l}\text { Hubei Maternal and Child } \\
\text { Health Care Hospital } \\
\text { (University) }\end{array}$ & Observational & Retrospective & Case series & Yes \\
\hline $\begin{array}{l}\text { COVID-19 biological samples } \\
\text { collection }\end{array}$ & France & $\begin{array}{l}\text { University Hospital, } \\
\text { Bordeaux }\end{array}$ & Observational & Prospective & Case-only & No \\
\hline $\begin{array}{l}\text { Clinical characteristics of coronavirus } \\
\text { disease } 2019 \text { (COVID-19) in pregnancy }\end{array}$ & Italy & $\begin{array}{l}\text { University of Naples Fed- } \\
\text { erico II } \\
\text { (University) }\end{array}$ & Observational & Prospective & Registry & Yes \\
\hline $\begin{array}{l}\text { Clinical characteristics of coronavirus } \\
\text { disease } 2019 \text { (COVID-19) in pregnancy: } \\
\text { the Italian Registry on coronavirus in } \\
\text { pregnancy }\end{array}$ & Italy & $\begin{array}{l}\text { University of Naples Fed- } \\
\text { erico II (University) }\end{array}$ & Observational & Prospective & Registry & Yes \\
\hline $\begin{array}{l}\text { COVID-19 during pregnancy: a pro- } \\
\text { spective Observational cohort }\end{array}$ & Netherlands & $\begin{array}{l}\text { Máxima Medisch Centrum } \\
\text { (University) }\end{array}$ & Observational & Prospective & Cohort & Yes \\
\hline $\begin{array}{l}\text { Outcomes of vascular surgery in } \\
\text { COVID-19 infection: National Cohort } \\
\text { Study }\end{array}$ & Spain & $\begin{array}{l}\text { Vascular Investigation } \\
\text { Network Spanish Society } \\
\text { for Angiology and Vascu- } \\
\text { lar Surgery }\end{array}$ & Observational & Prospective & Registry & No \\
\hline $\begin{array}{l}\text { UKOSS: pandemic COVID-19 in } \\
\text { pregnancy }\end{array}$ & United Kingdom & $\begin{array}{l}\text { NIHR/University of Oxford } \\
\text { (Government) }\end{array}$ & Observational & Prospective & Cohort & Yes \\
\hline $\begin{array}{l}\text { Outcomes of surgery in COVID-19 in- } \\
\text { fection: international cohort study } \\
\text { (CovidSurg) }\end{array}$ & United Kingdom & University of Birmingham & Observational & Prospective & Registry & No \\
\hline $\begin{array}{l}\text { Priority (pregnancy coronavirus out- } \\
\text { comes registry) }\end{array}$ & United States & University of California & Observational & Prospective & Registry & Yes \\
\hline
\end{tabular}

Abbreviations: COVID-19, coronavirus disease 2019; n/a, not applicable; NIHR, National Institute for Health Research; RCT, randomized controlled trial; SARS-CoV-2, severe acute respiratory syndrome coronavirus 2; UKOSS, UK Obstetric Surveillance System.

${ }^{a}$ These two trials were registered on clinicaltrials.gov on April 7, 2020 but were later removed. 


\section{Funding}

M.M.C. is supported by a grant from The Eunice Kennedy Shriver National Institute of Child Health and Human Development (grant number: 5 UG1 HD027915-29) and the National Heart, Lung, and Blood Institute (grant number: 1UG3HL140131-01). This manuscript does not necessarily represent the official views of the NICHD, NHLBI, or the National Institute of Health.

\section{Conflict of Interest}

None declared.

\section{References}

1 Blehar MC, Spong C, Grady C, Goldkind SF, Sahin L, Clayton JA. Enrolling pregnant women: issues in clinical research. Women's Heal Issues 2013. Doi: 10.1016/j.whi.2012.10.003

2 Shields KE, Lyerly AD. Exclusion of pregnant women from industrysponsored clinical trials. Obstet Gynecol 2013;122(05):1077-1081

3 Illamola SM, Bucci-Rechtweg C, Costantine MM, Tsilou E, Sherwin CM, Zajicek A. Inclusion of pregnant and breastfeeding women in research - efforts and initiatives. Br J Clin Pharmacol 2018;84(02):215-222

4 Mitchell AA, Gilboa SM, Werler MM, Kelley KE, Louik C, HernándezDíaz S; National Birth Defects Prevention Study. Medication use during pregnancy, with particular focus on prescription drugs: 1976-2008. Am J Obstet Gynecol 2011;205(01):51.e1-51.e8

5 Ayad M, Costantine MM. Epidemiology of medications use in pregnancy. Semin Perinatol 2015;39(07):508-511

6 McCormack SA, Best BM. Obstetric pharmacokinetic dosing studies are urgently needed. Front Pediatr 2014;2:9

7 Task Force on Research Specific to Pregnant Women and Lactating Women (PRGLAC). PRGLAC Report to the HHS Secretary and Congress, September 2018.; 2018. Available at: https://www. nichd.nih.gov/sites/default/files/2018-09/PRGLAC_Report.pdf. Accessed April 28, 2020

8 Ballantyne A. Pregnant women can finally expect better. Hastings Cent Rep 2019;49(01):10-11

9 Worldometer. Coronavirus Update (Live): 472,907 Cases and 21,315 Deaths from COVID-19 Virus Outbreak - Worldometer. Worldometer. Available at: https://www.worldometers.info/coronavirus/. Accessed April 28, 2020
10 World Health Organization. Coronavirus (COVID-19) events as they happen. WHO. Available at: https://www.who.int/emergencies/diseases/novel-coronavirus-2019/events-as-they-happen. Accessed April 28, 2020

11 WHO. Coronavirus Disease 2019 (COVID-19) Situation Report-79; 2020. Available at: https://www.who.int/docs/default-source/coronaviruse/situation-reports/20200408-sitrep-79-covid-19. pdf?sfvrsn=4796b143_6. Accessed April 28, 2020

12 Gonzalez D, Boggess KA, Cohen-Wolkowiez M. Lessons learned in pediatric clinical research to evaluate safe and effective use of drugs in pregnancy. Obstet Gynecol 2015;125(04): 953-958

13 Gomes MF, de la Fuente-Núñez V, Saxena A, Kuesel AC. Protected to death: systematic exclusion of pregnant women from Ebola virus disease trials. Reprod Health 2017;14(Suppl 3):172

14 Connor EM, Sperling RS, Gelber R, et al. Reduction of maternalinfant transmission of human immunodeficiency virus type 1 with zidovudine treatment. Pediatric AIDS Clinical Trials Group Protocol 076 Study Group. N Engl J Med 1994;331(18):11731180

15 Nayak S. Influenza vaccine requirements in pregnant women. J Obstet Gynecol India 2016. Doi: 10.1007/s13224-016-0867-1

16 Louie JK, Acosta M, Jamieson DJ, Honein MA; California Pandemic (H1N1) Working Group. Severe 2009 H1N1 influenza in pregnant and postpartum women in California. N Engl J Med 2010;362(01): 27-35

17 Newsome K, Williams J, Way S, et al; Centers for Disease Control and Prevention (CDC). Maternal and infant outcomes among severely ill pregnant and postpartum women with 2009 pandemic influenza A (H1N1)-United States, April 2009-August 2010. Morb Mortal Wkly Rep 2011;60(35):1193-1196

18 Saleeby E, Chapman J, Morse J, Bryant A, Nygaard I. H1N1 influenza in pregnancy: cause for concern. Obstet Gynecol 2009;114(04): 885-891

19 Goldkind SF, Sahin L, Gallauresi B. Enrolling pregnant women in research-lessons from the H1N1 influenza pandemic. N Engl J Med 2010;362(24):2241-2243

20 McKiever M, Frey H, Costantine MM. Challenges in conducting clinical research studies in pregnant women. J Pharmacokinet Pharmacodyn 2020. Doi: 10.1007/s10928-020-09687-z

21 Spong CY, Bianchi DW. Improving public health requires inclusion of underrepresented populations in research. JAMA 2018;319 (04):337-338 